\title{
Commercial oil of Nigella sativa as growth promoter in lambs rations
}

\author{
S. El-Naggar ${ }^{1 *}$, G.A. Abou-Ward ${ }^{1}$, A.Y. El-Badawi ${ }^{1}$, A.M. Ali ${ }^{2}$ \\ ${ }^{1}$ National Research Centre, Animal Production Department, Dokki, Giza, 12311, Giza, Egypt, ${ }^{2}$ Cairo University, Animal \\ Production Department, 12613, Giza, Egypt, *Corresponding Author soadelnaggar75@gmail.com
}

(Received January 28, 2018; Accepted February 23, 2018)

\begin{abstract}
This study aimed to investigate the impact of supplementing different levels of Nigella sativa oil in rations of growing lambs. In a feeding experiment lasted 90 days, 18 growing Ossimi lambs (6-7 months old) were randomly divided by weight into three equal groups ( 6 animals each). Individual animals in all groups were fed a uniform total mixed ration, offered at $3 \%$ of body weight, where the first group was without supplement (R1), while Nigella sativa oil was supplemented at 0.1 (R2) and $0.2 \%$ (R3) of dietary DM. Results indicated that additions of $N$. sativaoil didn't influenced feed intake, but it increased average body weight gain and feed efficiency. Nutrients digestibility values and dietary nitrogen utilization were higher with $N$. sativaoil rations than control. Ruminal fermentation parameters showed comparable $\mathrm{pH}$ values among groups at 0,3 and $6 \mathrm{hrs}$. of feeding. Ruminal $\mathrm{NH}_{3}-\mathrm{N}$ concentration was lower and TVFA concentration was higher for animal fed $\mathrm{R} 2$ and $\mathrm{R} 3$ rations than control. It's concluded that $N$. sativa oil could be added at $0.2 \%$ of the daily feed as a natural growth enhancer of lambs.
\end{abstract}

Keywords: Nigella sativa oil, lambs nutrients digestibility, growth performance Available online at http://www.vetmedmosul.com

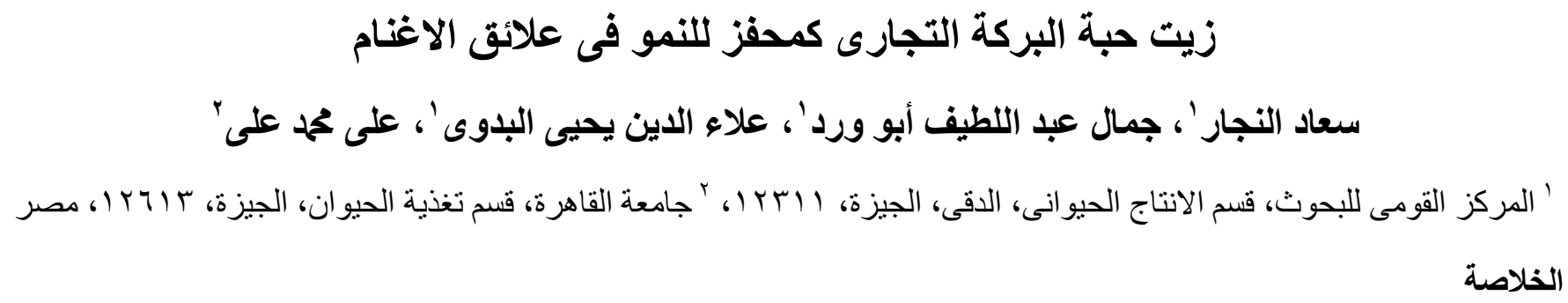

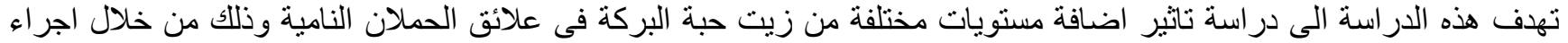

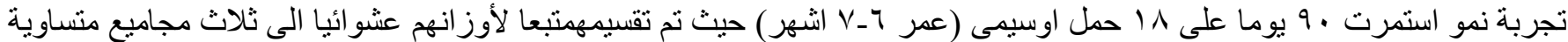

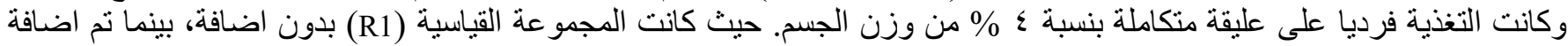

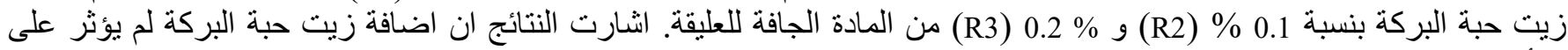

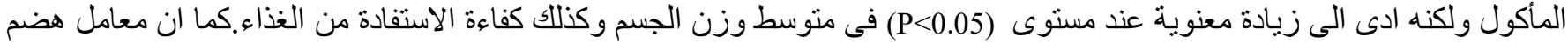

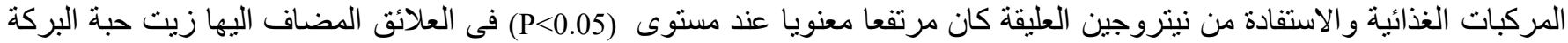

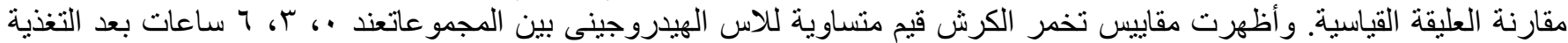

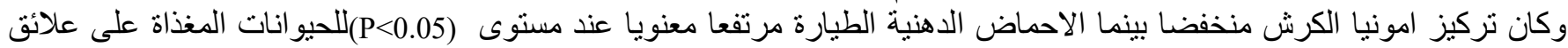
تحتوى زيت حبة البركة مقارنة بالعليقة القياسية. ويمكن استتناج ان اضافية الافية زيت حبة البركة حتى مستوى \% 0.2 للتغذية اليومية يعتبر محسن طبيعى لنمو للحملان.

\section{Introduction}

In animal production, antibiotics are commonly fed to animals to prevent disease and metabolic disorders, as well as improve feed efficiency. However, the World Health
Organization classifies the antibiotic resistance as one of the highest impendence to human health. So, there is a need for use alternative additives instead of antibiotics in animal feeding (1) like essential oils which considered safe for animal consumption followed by humane, and recognized 
as safe (2) in the USA. The antimicrobial properties of EO have been demonstrated against a wide range of microorganisms, including bacteria, protozoa and fungi (35) which may lead to improve nutrients digestibility. Several experiments suggested that the addition of plants or plant extracts rich in bioactive compounds to ruminant rations might have beneficial effects on ruminal fermentation, thus enhancing degradation processes. Whereas, (6-8) indicated that essential oils (EO) can be used as growth promoters and have antimicrobial properties which modulate ruminal fermentation and improve nutrient utilization in ruminants.

Nigella sativa is one of the very important medicinal plants, which used for centuries in Middle East as a healer of many complains and disease (9) and is commonly known as black seed which its oil is containing linoleic $60 \%$, oleic $22 \%$ and palmitic $12 \%$ as major fatty acids (10). Also, it can be used as antioxidant agent via inhibiting the nonenzymatic peroxidation which may increase the immunity of animals and improve their health and growth performance. (11) suggested that supplementation of $N$. sativa oil to ruminants ration acts as additional source of PUFA which are very important for animals health.

The objective of this work was to evaluate the effects of $N$. sativa oil additive as a natural growth enhancer of Egyptian Ossimi lambs.

\section{Materials and methods}

\section{Preparation of experimental rations}

The basal total mixed ration (TMR) consisted of $40 \%$ wheat straw, $25 \%$ ground yellow corn, $20 \%$ soybean meal, $11 \%$ wheat bran, $1.5 \%$ minerals and vitamins mixture, 0.8 $\%$ salts and $1.7 \%$ limestone was used without additives as control ration (R1). While, two levels of Nigella sativa oil (extracted by coaled pressing using hydraulic press system) being 0.1 and $0.2 \%$ of $\mathrm{DM}$ were hand mixed with other feed ingredients for R2 and R3 groups, respectively.

\section{Feeding trial}

Eighteen growing Ossimi lambs aged 6-7 months old with $29.04 \mathrm{~kg}$ average body weight were divided by weight into three equal groups (6animals each) in a feeding trial lasted 90 days. Animals of all groups were fed individually on experimental rations offered at $4 \%$ of live body weight. Daily amounts of TMR were biweekly adjusted according to body weight changes. Feed intake was daily recorded, and refusals (if any) were daily collected and weighed. Clean drinking water was freely available at all times.

\section{Digestibility trials}

At the end of the feeding experiment three digestibility trials were carried out on three random sheep from each group over a period of 14 days, where 7 days were for adaptation and the other seven days for quantitative collection of feces and urine. Daily amounts of feed intake, feces and urine out-put were measured and daily recorded during the collection period. Dried samples of feces and feeds were ground to pass through 1-mm sieve, and stored in emeried bottles for chemical analysis. Samples of acidified urine were kept in clean dry glass bottles until nitrogen determination. Ruminal fluid samples were collected at the end of the experiment via a rubber stomach tube before feeding then at 3 and $6 \mathrm{hrs}$. after feeding. Samples of rumen content, for each animal, were filtered through four layers of cheesecloth, and then ruminal $\mathrm{pH}$ was immediately recorded using digital $\mathrm{pH}$ meter, then samples were stored at $-20 \mathrm{C}$ for latter ammonia and volatile fatty acids determination.

\section{Chemical analysis}

Chemical composition of experimental rations and feces were determined for dry matter (DM), crude protein $(\mathrm{CP})$, crude fiber (CF), ether extract (EE) and ash according to the standard methods of (12). Nitrogen free extract (NFE) was calculated by difference. Urinary nitrogen (UN) was determined by the micro-kjeldahl method. Ruminal ammonia nitrogen $\left(\mathrm{NH}_{3}-\mathrm{N}\right)$ concentration was determined applying the micro diffusion method (13) and ruminal total volatile fatty acids (TVFA's) concentrations was determined according to (14).

\section{Statistical analysis}

Collected data concerning body weight gain, feed efficiency, nutrients digestibility and dietary nitrogen utilization were subjected to one-way analysis of variance according to (15) applying the general linear model procedure of (16). While, data of the rumen parameter was subjected to two-way analysis by the same previous procedure. Significant differences between means were tested at $(\mathrm{P}<0.05)$ using $(17)$.

\section{Results and discussion}

Data of dietary chemical composition given in Table (1) indicate that the theoretically calculated nutritive value of the experimental TMR was nearly $70 \%$ as total digestible nutrients (TDN) and $12 \%$ as digestible crude protein (DCP) units. These values are sufficient to cover the nutritional requirements needed for growing local breeds of sheep when the experimental diet is fed at $4 \% \mathrm{DM}$ of body weight as recommended by the (18).

Mean daily feed intake; average daily gain and feed efficiency are presented in Table (2). It seems that feed intake did not influenced by $N$. sativa supplementation, however the slight insignificant increase of feed consumption for $N$. sativa groups than control is regarded to body weight fluctuation among groups, since animals 
were fed on restricted amounts being $3 \%$ of body weight, was observed. Final body weight and average daily body weight gain were higher by 4.72 and $13.9 \%$ for R2 and 7.1 and $20 \%$ for R3 compared with R1. Feed utilization efficiency was significantly $(\mathrm{P}<0.05)$ improved with supplemented diets (6.64, R1, vs. 6.19, R2, and 5.96, R3). Meanwhile, (19) stated that dietary supplementation with cinnamaldehyde increased DMI of feedlot cattle in the early weeks of the fattening period. The present results concerning effect of essential oils supplementation on improving weight gain and feed utilization efficiency were in agreement with the findings of (20-11). The development of body weight with advancing feeding period shown in Fig. (1), illustrate that animals of the control were better than other groups up to the sixth week of the feeding period, while animals fed $N$. sativa diets showed better weight gain than control afterwards till the end of the experimental feeding period, and the best result was attained with R3 (0.2\%N.sativadiet). In other words, we can state that the beneficial effect of $N$. sativa oil on weight gain of sheep might need six weeks more or less, depends on; supplementation level, previous feeding status, feed allowances, type and age of animals and the environmental conditions.

Table 1: Chemical composition of experimental rations

\begin{tabular}{lc}
\hline Item & $\%$ \\
\hline Moisture & 09.44 \\
\hline Dry matter composition (DM & \\
\hline Organic matter (OM) & 93.90 \\
Crude protein (CP) & 13.59 \\
Crude fiber (CF) & 19.99 \\
Ether extract (EE) & 02.47 \\
Nitrogen free extract (NFE) & 57.85 \\
Ash & 06.10 \\
\hline
\end{tabular}

Table 2: Feed intake, average daily body weight gain and feed efficiency of sheep fed experimental rations

\begin{tabular}{lcccc}
\hline Item & $\mathrm{R} 1$ & $\mathrm{R} 2$ & $\mathrm{R} 3$ & $\pm \mathrm{SE}$ \\
\hline Initial BW, Kg & 29.00 & 29.00 & 29.13 & 3.54 \\
Final BW, Kg & $43.85^{\mathrm{b}}$ & $45.92^{\mathrm{a}}$ & $46.95^{\mathrm{a}}$ & 2.24 \\
Average daily BW gain, g & $165^{\mathrm{b}}$ & $188^{\mathrm{a}}$ & $198^{\mathrm{a}}$ & 11.00 \\
Daily intake, g & 1095 & 1163 & 1180 & 93.92 \\
Feed efficiency, (Kg intake/Kg gain) & $6.64^{\mathrm{b}}$ & $6.19^{\mathrm{a}}$ & $5.96^{\mathrm{a}}$ & 0.20 \\
\hline
\end{tabular}

a,b,c Means have different superscripts in the same row are significantly different at $(\mathrm{P}<0.05)$.

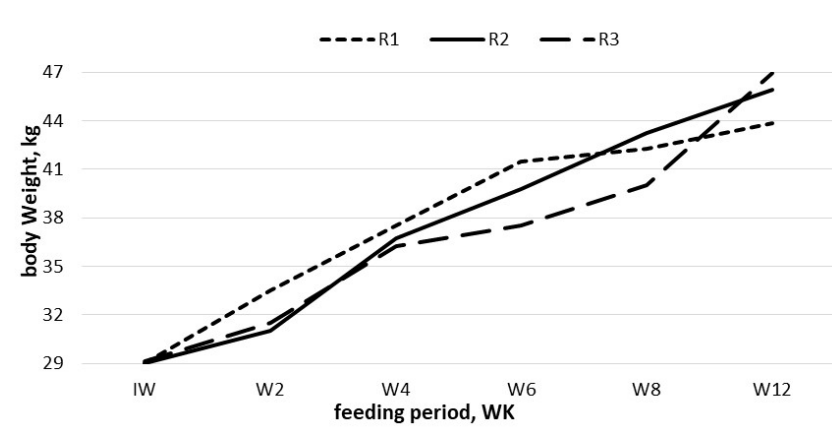

Fig. 1: Development of body weight for lambs fed experimental rations.

Data of nutrients digestibility and nutritive value of the experimental rations presented in Table (3) show that there were a significant $(\mathrm{P}<0.05)$ increases in the digestibility of DM, OM, CP and NFE of R2 and R3 (73.04, 78.79, 75.57 and 85.86) and $(76.62,80.20,78.32$ and 86.29), respectively compared to $64.77,71.84,73.96$ and $76.60 \%$ in the same order for R1. Nutritive values had the same trend as digestibility values, where, TDN and $\mathrm{DCP} \%$ were significantly $(\mathrm{P}<0.05)$ higher for $\mathrm{R} 2$ and $\mathrm{R} 3$ than those of $\mathrm{R} 1$ and the highest values were recorded for R3. This improvement in nutrients digestion with R2 and R3 might be due to the stimulatory effect of essential oil (EO) on digestion process in the rumen. This result is in agreement with the findings of (21) who found that supplementation with $50 \mathrm{mg}$ black seed oil in in-vitro trial tended to increase in vitro $\mathrm{DM}$ and organic matter disappearance compared with control, In the contrast, (22) found that addition of EO had no significant effect on total tract digestibility of dry matter, organic matter, crude protein and crude fiber. Such variation in results among researches might be due to that the response to EO in ruminants varies with the species, type and dose of EO, diet composition and whether the effect was investigated by in vivo or in vitro application (23-24).

Dietary nitrogen balance and utilization values shown in Table (4) indicated that, there was a significant $(\mathrm{P}<0.05)$ increase in nitrogen balance $(\mathrm{g} / \mathrm{h} / \mathrm{d})$ for sheep fed either $\mathrm{R} 2$ or R3 compared with those fed R1 being, 9.89 (R2) and 14.19 (R3) vs. 7.9 for control. Apparent dietary nitrogen utilization calculated as $\mathrm{N}$-balance relative to $\mathrm{N}$-intake or digestible-N showed similar significant trend for $N$. sativa 
oil supplemented diets in comparison with control. It's interesting to note that the urinary $\mathrm{N}$ loss was highly decreased with increasing the level of supplementation. In some previous studies on rabbits, it was mentioned similar results of lower $\mathrm{N}$ excretion with Moringa oleifera dry leaves (25) and with $S$. cerevisae and B. subtilis (26). It seems that the natural-bio additives are not only improving nutrients digestibility particularly protein but also improving nutrients absorption and utilization post digestion.

Table 3: Nutrients digestibility and nutritive value of experimental rations

\begin{tabular}{lcccc}
\hline Item & $\mathrm{R} 1$ & $\mathrm{R} 2$ & $\mathrm{R} 3$ & \pm SE \\
\hline \multicolumn{1}{l}{ Nutrients digestibility, \% } & & & \\
\hline DM & $64.77^{\mathrm{b}}$ & $73.04^{\mathrm{a}}$ & $76.62^{\mathrm{a}}$ & 4.26 \\
OM & $71.84^{\mathrm{c}}$ & $78.79^{\mathrm{a}}$ & $80.20^{\mathrm{a}}$ & 2.91 \\
CP & $73.96^{\mathrm{c}}$ & $75.57^{\mathrm{b}}$ & $78.32^{\mathrm{a}}$ & 1.54 \\
EE & $76.88^{\mathrm{b}}$ & $80.75^{\mathrm{ab}}$ & $82.05^{\mathrm{a}}$ & 2.55 \\
CF & $56.03^{\mathrm{b}}$ & $60.28^{\mathrm{ab}}$ & $61.92^{\mathrm{a}}$ & 2.14 \\
NFE & $76.60^{\mathrm{b}}$ & $85.86^{\mathrm{a}}$ & $86.29^{\mathrm{a}}$ & 3.57 \\
\hline Nutritive value, $\%$ & & & & \\
\hline TDN & $69.83^{\mathrm{b}}$ & $76.48^{\mathrm{a}}$ & $77.50^{\mathrm{a}}$ & 3.04 \\
CPD & $11.73^{\mathrm{c}}$ & $12.1^{\mathrm{b}}$ & $12.53^{\mathrm{a}}$ & 0.10 \\
\hline
\end{tabular}

a,b,c Means have different superscripts in the same row are significantly different at $(\mathrm{P}<0.05)$.

Table 4: Effect of feeding experimental rations on nitrogen utilization of sheep

\begin{tabular}{lcccc}
\hline Item & $\mathrm{R} 1$ & $\mathrm{R} 2$ & $\mathrm{R} 3$ & $\pm \mathrm{SE}$ \\
\hline $\mathrm{N}$ intake, g/h/d & 28.61 & 30.00 & 30.61 & 0.85 \\
Fecal nitrogen, g/h/d & $7.46^{\mathrm{a}}$ & $7.32^{\mathrm{b}}$ & $6.64^{\mathrm{c}}$ & 0.86 \\
Urinary nitrogen, g/h/d & $13.25^{\mathrm{a}}$ & $12.79^{\mathrm{a}}$ & $9.78^{\mathrm{b}}$ & 1.21 \\
Nitrogen balance, g & $7.90^{\mathrm{c}}$ & $9.89^{\mathrm{b}}$ & $14.19^{\mathrm{a}}$ & 1.25 \\
\hline Dietary N utilization, \%: & & & & \\
\hline of N intake & $27.61^{\mathrm{c}}$ & $32.96^{\mathrm{b}}$ & $47.67^{\mathrm{a}}$ & 1.47 \\
of digestible N & $37.33^{\mathrm{c}}$ & $43.62^{\mathrm{b}}$ & $59.20^{\mathrm{a}}$ & 1.32 \\
\hline
\end{tabular}

a,b,c Means have different superscripts in the same row are significantly different at $(\mathrm{P}<0.05)$.

The histograms of measured rumen fermentation parameters ( $\mathrm{pH}, \mathrm{NH}_{3}-\mathrm{N}$ and TVFAs) given in Figs. 2, 3 and 4 illustrate that all parameters recorded the highest values after $3 \mathrm{hrs}$ of feeding with noticeable lower ammonia-N and higher TVFAs concentrations for animals fed $N$. sativa oil diets. Data in Table (5) indicate that, there was a significant $(\mathrm{P}<0.05)$ decrease in the overall mean of ruminal ammonia by 11.9 and $22.9 \%$ but there was a significant $(\mathrm{P}<0.05)$ increase in the rumen volatile fatty acids by 12.4 and $15.1 \%$, respectively for R2 and R3 compared with R1.These results are in agreement with (21) who reported that $\mathrm{NH}_{3}-\mathrm{N}$ concentration decreased and VFA conc. increased in the ruminal fluid samples with black seed oil supplementation. According to some earlier studies, it was concluded that the addition of bio-active substances are influencing ruminal ammonia and TVFAs $(6,7,27)$, with no significant effect on $\mathrm{pH}(28-31)$.

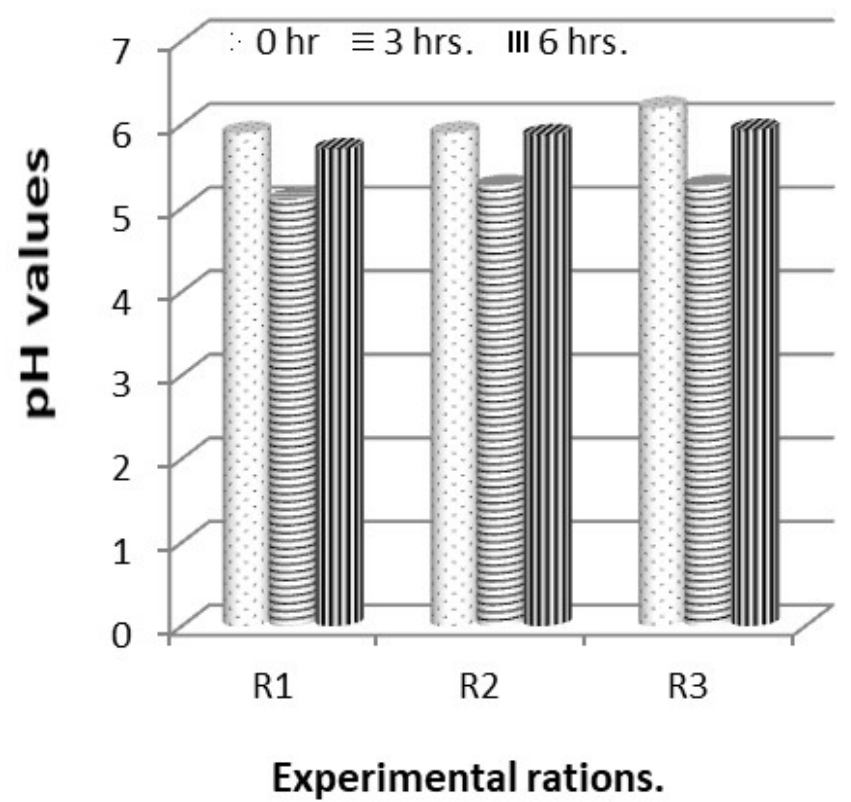

Fig. 2: Ruminal $\mathrm{pH}$ values at 0,3 and $6 \mathrm{hrs}$ of feeding experimental rations.

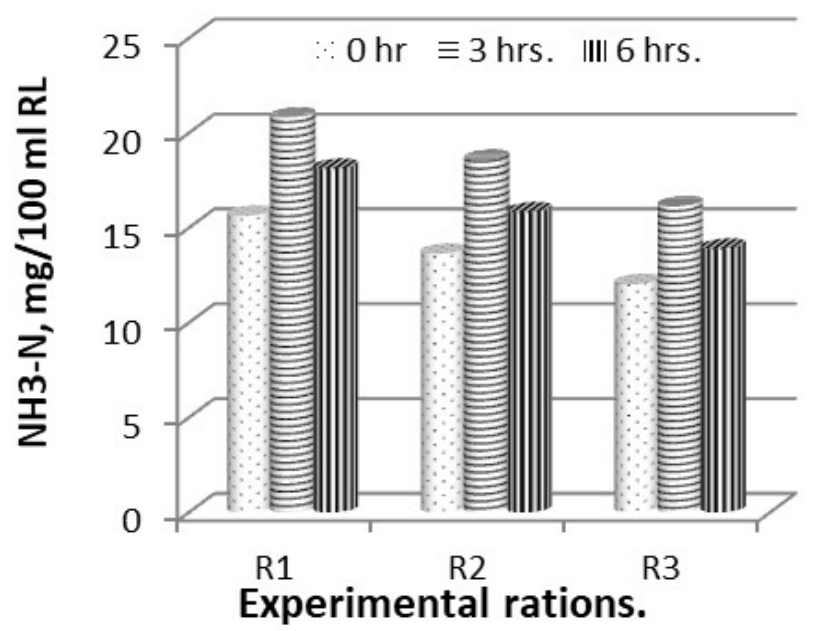

Fig. 3: Ruminal NH3-N concentration at 0,3 and 6 hrs of feeding experimental rations. 


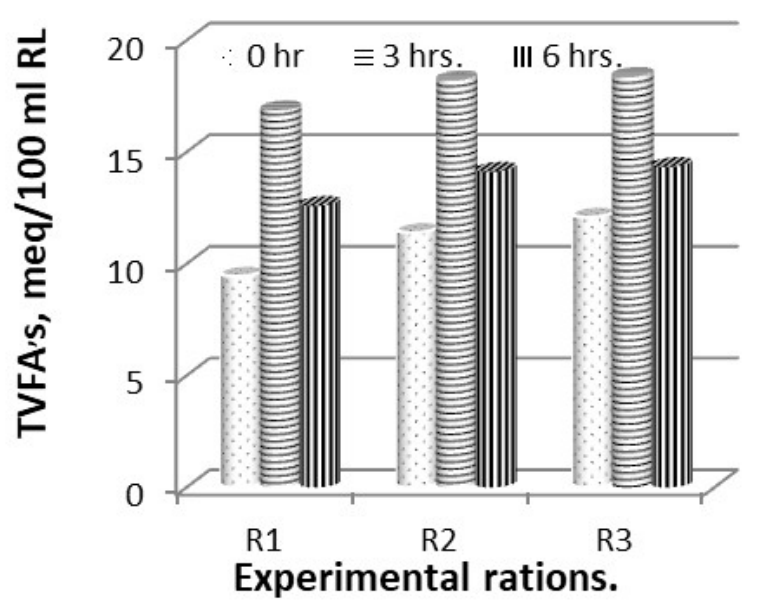

Fig. 4: Ruminal TVFA's concentrations at 0,3 and $6 \mathrm{hrs}$ of feeding experimental rations.

Table 5: Overall mean of rumen parameters of sheep fed experimental rations

\begin{tabular}{lllll}
\hline Item & \multicolumn{1}{c}{$\mathrm{R} 1$} & \multicolumn{1}{c}{$\mathrm{R} 2$} & \multicolumn{1}{c}{$\mathrm{R} 3$} & \multicolumn{1}{c}{$\pm \mathrm{SE}$} \\
\hline $\mathrm{pH}$ & 0.22 & 5.80 & 5.68 & 5.57 \\
$\mathrm{NH}_{3}-\mathrm{N}, \mathrm{mg} / \mathrm{ml} \mathrm{RL}$ & 0.9 & $14.02^{\mathrm{c}}$ & $16.01^{\mathrm{b}}$ & $18.18^{\mathrm{a}}$ \\
TVFA's,meq/dl RL & 0.84 & $14.93^{\mathrm{a}}$ & $14.58^{\mathrm{a}}$ & $12.97^{\mathrm{b}}$ \\
\hline
\end{tabular}

$\mathrm{a}, \mathrm{b}, \mathrm{c}$. Means with different superscripts in the same row differ significantly $(\mathrm{P}<0.05)$.

From the previous results it could be concluded that addition of Nigella sativa oil at $0.2 \%$ of DM in diets of sheep is recommended to improve feed utilization and growth performance of growing Ossimi sheep.

\section{References}

1. Benchaar C, Calsamigilla S, Chaves AV, Fraser GR, Colombatto D, Mcallister TA and Beauchemin KA. A review of plant-derived essential oils in ruminant nutrition and production. Animal Feed Sci Technol. 2008;145(1-4):209-228.

2. FDA. Food and Drug Administration of the US, 21 CFR 184. Online. 2004; Available at: http://www.cfsan.fda.gov/eafus.html.

3. Dean SG, Ritchie G. Antibacterial properties of plant essential oils. Int J Food Microbiol. 1987;5:165-180.

4. Sivropoulou A, Papanikolaou E, Nikolaou C, Kokkini S, Lanaras T, Arsenakis M. Antimicrobial and cytotoxic activities of Origanum essential oils. J Agric Food Chem. 1996;44:1202-1205.

5. Chao SC, Young DG,Oberg CJ. Screening for inhibitory activity of essential oils on selected bacteria, fungi and viruses. J Essent Oil Res. 2000;12:639-649.

6. Calsamiglia S, Busquet M, Cardozo PW, Castillejos L, Ferret A. Invited review: essential oils as modifiers of rumen microbial fermentation. J Dairy Sci. 2007;90:2580-2595.

7. Hart KJ, Yanez-Ruiz DR, Duval SM, McEwanand NR, Newbold CJ. Plant extracts to manipulate rumen fermentation. Animal Feed Sci Tech. 2008;147:8-35.
8. Zhang W, Xiao S, Samaraweera H, Lee EJ, Ahn DU. Improving functional value of meat products. Meat Sci. 2010;86(1):15-31.

9. Houghton PZ, Heras B, Holt JR. Fixed oil of Nigella sativa and derived thymoquinon inhibit eicosanoid generation in leukocytes and membrane lipid peroxidation. Planta Med. 1995;61:33-36.

10. Ustun G, Kent N, Cekin N, Civelekoglu H. Investigation of the technological proportion of Nigella sativa (black cumin) seed oil. J Amer Chem Soci. 1990;67(17):958-960.

11. Idris HM, El-BagirNabeila M, Al-Tayib OA. Effect of commercial oil of Nigella sativa L. seeds on lipids parameters and weight in sheep. Pharma Innova J. 2014;3(7):87-91.

12. AOAC, Official Methods of Analysis of AOAC International, $19^{\text {th }} \mathrm{Ed}$. Vol.1, "Animal feed". Maryland, USA, 2012; chapter 4:1-77.

13. Conway EH. Micro diffusion analysis and volumetric error. $5^{\text {th }} \mathrm{Ed}$. Crosby Lockwood and Sons Ltd., London.1957.

14. Warner ACI. Production of volatile fatty acid in the rumen 1: Method of measurement. Nutr Abstr Rev. 1964;34:339.

15. Steel RGD, Torrie JH. Principles and Procedures of Statistics.A biometrical approach. $2^{\text {nd }}$ edition. McGraw-Hill, New York, USA. 1980; pp:20-90.

16. SAS.Statistical Analysis Systems (SAS) Institute Inc., 2002.SAS/ STAT. User.

17. Duncan DB. Multiple Range and Multiple (F-test). Biometrics. 1955;11:1-42.

18. NRC,1985,. Nutrient requirements of sheep. National Research Council. ( $6^{\text {th }}$ ed.). National Academy Prees. Washington, D. C. USA.pp:99.

19. Yang WZ, Ametaj BN, He ML, Benchaar C, Beauchemin KA. Cinnamaldehyde in feedlot cattle diets: intake, growth performance, carcass characteristics, and blood metabolites. J Anim Sci. 2010;88:1082-1092.

20. Haddad SG, Goussous SN. Effect of yeast culture supplementation on nutrient intake, digestibility and growth performance of Awassi lambs. Anim Feed Sci Tech. 2005;118:343.

21. Klevenhusen FDK, Sizmaz Ö, Wimmer S, Muro-Reyes A, KhiaosaArd R, Chizzola R,Zebeli Q. Effects of black seed oil and Ferula elaeochytris supplementation on ruminal fermentation as tested in vitro with the rumen simulation technique (Rusitec). Anim Prod Sci. 2015: http://dx.doi.org/10.1071/AN13332.

22. Abdallah M, Deml M, Fahn C,Windisch W. Effects of a Specific Blend of Essential Oil on Rumen Degradability, Total Tract Digestibility and Fermentation Characteristics in Rumen Fistulated Cows. J Dairy Vet Anim Res. 2016;3(2):72.

23. Noirot V, Moncoulon R, Sauvant D, Bayourthe C. Effect of essential oils and essential oils com-pounds supplementations in ruminant species: statistical analysis. Revue Méd Vét. 2007;158:589-597.

24. Klevenhusen F, Muro-Reyes A, Khiaosa-ard R, Metzler-Zebeli BU, Zebeli Q. A meta-analysis of effects of chemical composition of incubated diet and bioactive compounds on in vitro ruminal fermentation. Anim Feed Sci Technol. 2012;176:61-69.

25. El-Badawi AY, Omer HAA, Abedo AA, Yacout MHM. Response of growing New Zealand white rabbits to rations supplemented with different levels of Moringa oleifera dry leaves. Global Veterinaria. 2014; 12:573-582.

26. El-Badawi AY, Helal FIS, Yacout MHM, Hassan AA, Soad ElNaggar,Eman H. Alsabaawy. Growth performance of male NEW rabbits fed diets supplemented with beneficial bacteria or live yeast. International Conference on "Advanced Technologies and their Applications in Agriculture". 2017; 27 to 29 March, Cairo, Egypt.

27. Benchaar C, Greathead H. Essential oils and opportunities to mitigate enteric methane emissions from ruminants. Ani Feed Sci Technol. 2011;166-167:338-355.

28. Cardozo PW, Calsamiglia S, Ferret A, Kamel C. Effects of alfalfa extract, anise, capsicum, and a mixture of cinnamaldehyde and eugenol on ruminal fermentation and protein degradation in beef heifers fed a high-concentrate diet. J Anim Sci. 2006;84:2801-2808. 
29. Fandino I, Calsamiglia S, Ferret A, Blanch M. Anise and capsicum as alternatives to monensin to modify rumen fermentation in beef heifers fed a high concentrate diet. Anim. Feed Sci Tech. 2008;145:409-417.

30. Meyer NF, Erickson GE, Klopfenstein TJ, Greenquist MA, Luebbe MK, Williams P. Engstrom MA. Effect of essential oils, tylosin and monensin on finishing steer performance, carcass characteristics, liver abscesses, ruminal fermentation and digestibility. J Anim Sci. 2009; 87:2346-2354.

31. Yang WZ, Ametaj BN, Benchaar C, Beauchemin KA. Dose response to cinnamaldehyde supplementation in growing beef heifers: ruminal and intestinal digestion. J Anim Sci. 2010;88:680-688. 